\title{
TITLE:
}

\section{Nonohmic Properties of Zinc Oxide Ceramics(Abstract_要旨)}

$\operatorname{AUTHOR}(\mathrm{S})$ :

Matsuoka, Mitsuo

\section{CITATION:}

Matsuoka, Mitsuo. Nonohmic Properties of Zinc Oxide Ceramics. 京都大 学, 1971, 理学博士

ISSUE DATE:

1971-11-24

URL:

http://hdl.handle.net/2433/213787

RIGHT: 


\section{【60 】}

$\begin{array}{lllll}\text { 氏名 } & \text { 松 } & \text { 岡 } & \text { 道 } & \text { 雄 } \\ \text { 学位の種類 } & \text { 理 } & \text { 学 } & \text { 博 } & \text { 土 }\end{array}$

学 位記番号論理 博第 368 号

学位授与の日付昭和 46 年 11 月 24 日

学位授与の要件 学. 位 規則第 5 条第 2 項該当

学位論文題目 Nonohmic Properties of Zinc Oxide Ceramics

（酸化亜鈆焼結体の非オーム性）

論文調查委員教授高田利夫教授可知祐次教授水渡英二

\section{論文内容の要旨}

申請論文は酸化互鉛 $(\mathrm{ZnO})$ に特定の金属酸化物，たとえば $\mathrm{Bi}_{2} \mathrm{O}_{3}, \mathrm{CoO}, \mathrm{MnO}, \mathrm{Cr}_{2} \mathrm{O}_{3}, \mathrm{Sb}_{2} \mathrm{O}_{3}$ などを 単一あるいは複合添加した燒結体が非オーム性の電圧電流特性を示すことを見出し，この現象は焼結体の 微細構造によることを実験的に確かめ, 理論的にも検討を加えたものである。

申請者は, まず, 種々の添加物を単一あるいは複合添加した焼結体の電圧電流特性について検討を加え た結果, $\mathrm{ZnO}$ に $\mathrm{Al}_{2} \mathrm{O}_{3}$ や $\mathrm{In}_{2} \mathrm{O}_{3}$ を添加した場合は従来知られている原子価制御の原理にしたがって, 比抵抗は低くオーム性の特性を示すが， $\mathrm{Bi}_{2} \mathrm{O}_{3}$ や $\mathrm{Sb}_{2} \mathrm{O}_{3}$ を加えた場合は，原子価制御の原理にしたがわ ず，高抵抗でかつ非オーム性の燒結体が得られることを見出している。このような $\mathrm{ZnO}$ 燒結体に捛ける 非オーム性は $\mathrm{Bi}_{2} \mathrm{O}_{3}$ や $\mathrm{Sb}_{2} \mathrm{O}_{3}$ 以外にも $\mathrm{CaO}, \mathrm{SrO}, \mathrm{BaO}, \mathrm{CoO}, \mathrm{MnO}$ などを単一あるいは複合添加する ことによっても得られるが，複合添加すると非オーム性係数 $\alpha(\alpha=\mathrm{d}(\log \mathrm{I}) / \mathrm{d}(\log \mathrm{V}) ： \mathrm{I}$ は電流，Vは 電圧を示す) (著しく大きくなり，たとえば $\mathrm{Bi}_{2} \mathrm{O}_{3}, \mathrm{CoO}, \mathrm{MnO}, \mathrm{Cr}_{2} \mathrm{O}_{3}$ を各 0.5 モル\%, $\mathrm{Sb}_{2} \mathrm{O}_{3}$ を 1 モ ル\%複合添加した場合は $\alpha$ の值は 50 以上となりゼナーダイオードに匹敵する鋭い電流の立上り特性を示 すことを見出している。

次に申請者はこの非オーム性の原因を解明するために焼結体の微紐構造について電子顕微鏡，X線マイ クロアナライザーなどによって検討を加えている。その結果, 非オーム性を示す焼結体ではいずれの場合 でも添加物のほとんどは焼結体中の ZnO 䊀子中に固溶せず, 焼結微料子の境界に粒子を包んだ形で偏析 層をなしていることを見出している。この結論は非オーム性の焼結体を上記の方法で検討した結果のみな らず，次の実験結果からも裏づけされるとしている。すなわち、アルカリ土金属酸化物でも $\mathrm{BeO}$ や $\mathrm{MgO}$ を添加しても非オーム性を示さないが, この場合は $\mathrm{Be} や \mathrm{Mg}$ イオンが $\mathrm{ZnO}$ 中に固溶し偏析層は存 在せず，また $\mathrm{Bi}_{2} \mathrm{O}_{3}$ ，を添加した場合や前記 5 種類の添加物を複合添加した場合でも焼結温度が前者では $1250^{\circ} \mathrm{C}$ 以上, 後者では $1450^{\circ} \mathrm{C}$ 以上になると非オーム性を示さなくなるが, これらの場合は焼結中に $\mathrm{Bi}_{2} \mathrm{O}_{3}$ や $\mathrm{Sb}_{2} \mathrm{O}_{3}$ が弥発したり $\mathrm{CoO}, \mathrm{MnO}, \mathrm{Cr}_{2} \mathrm{O}_{3}$ が $\mathrm{ZnO}$ 中に固溶して, 燒結または偏析層が存在しな 
くなる事実を実験的に確かめている。

次にこれらの焼結体の電気的特性の測定結果から非オーム性 $\mathrm{ZnO}$ 焼結体を構成する焼結粒子の比抵抗 は $1 \sim 10 \Omega \mathrm{cm}$ であるに対し，偏析層の比抵抗は $10^{10} \Omega \mathrm{cm}$ 以上の值をもっていることや誘電率 $\varepsilon_{\mathrm{L}}$ は $\mathrm{ZnO}$ や各種の添加物が 10 程度であるに対し, 偏析層は 100 以上の值を示すとしており，この結果から偏 析層は酸化物の単なる混合物ではなく，化合物を形成しているものと推論している。

以上の結果から， $\mathrm{ZnO}$ 焼結体に見出された非オーム性は添加物の偏析により形成された粒子境界部の 高抵抗層に強電界が集中することによって起こると考え，うすい絶縁層を介しての非オーム性伝導機構に ついて実験結果と刘比して検討を加えている。すなわち上記 5 種の添加物を複合添加した燒結体では焼結

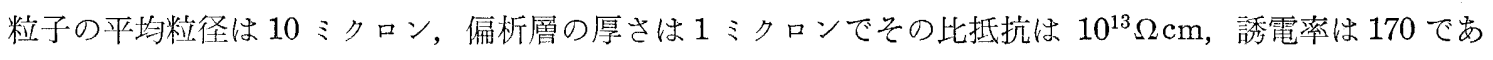
り，その非オーム性係数 $\alpha$ は50を示すことを認められているが，これらの実験值を考慮に入れるとうす

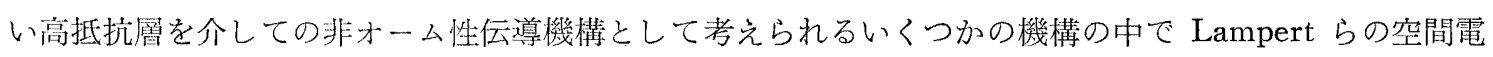
荷制限電流の理論がこの現象をもっともよく説明することを具体的な計算によって指摘している。

参考論文 6 編のうち， 2 編は主論文の先駆をなすものであり，他の 4 編は $\mathrm{SiC}$ の非オーム性焼結体に 関する研究である。

\section{論文 審 查の結 果の要旨}

酸化亜鉛 $(\mathrm{ZnO})$ は代表的な酸化物半導体として従来から単結晶, 焼結体あるいは薄膜などの形でその 電気的特性が広く研究されてきたが，これらはいずれも ZnOのn型半導性をもととしてその原子価制御 の効果を研究したものであって, これらの電気的特性はオーム性の範囲に入るものでめった。

これに対して申請者は $\mathrm{ZnO} に \mathrm{Bi}_{2} \mathrm{O}_{3}, \mathrm{CaO}, \mathrm{BaO}, \mathrm{SrO}, \mathrm{MnO}, \mathrm{Sb}_{2} \mathrm{O}_{3}$ などの添加物を単一あるいは複 合添加した麻結体が非オーム性の電圧電流特性を示すことを見出した。主論文はこの現象について, 検討 し, 非オーム性は焼結体の微細構造と関係あることを実験的に認め, 理論的にも考察を加えたものである。

すなわち，申請者は種々の酸化物を単一めるいは複合添加した $\mathrm{ZnO}$ 焼結体について種々の条件を変え た試料を作成し，電圧電流特性を検討した結果，オーム性に従うものと非オーム性特性を示すものとがあ ることを見出した。上記酸化物を単一添加した場合にも非オーム性を示すが，これらを複合添加すると非 オーム性係数 $\boldsymbol{\alpha}\left(\boldsymbol{\alpha}=\mathrm{d}(\log \mathrm{I}) / \mathrm{d}(\log \mathrm{V}): \mathrm{I}\right.$ は電流, V は電圧) が高くなり, 特に $\mathrm{Bi}_{2} \mathrm{O}_{3}, \mathrm{CoO}, \mathrm{MnO}, \mathrm{Cr}_{2} \mathrm{O}_{3}$ を各 0.5 モル\%, $\mathrm{Sb}_{2} \mathrm{O}_{3}$ を 1 モル\%複合添加した場合は $\boldsymbol{\alpha}$ の值が50以上のものが再現性よく得られるこ とを見出している。

このような焼結体についてその微細棈造を電子顕微鏡とX線マイクロアナライザーを用いて検討した結 果, 非オーム性を示す焼結体では添加物のほとんどが焼結体の焼結粒子の境界に粒子を包んだ形で偏析層 をなしていることを認め，これが非オーム性焼結体の一般性であると結論して以下の考察をすすめてい る。この結諭は数多くの種類の添加物について, 焼結条件を種々異ならせた焼結体を検討して得られたも のであり，一方，添加物を加えた場合でもオーム性を示す場合には上記の偏析層が認められないことも確 かめていて，妥当な結論と考えられるものである。

申請者はこれら非オーム性焼結体について電気的特性を測定した結果から，焼結粒子の比抵抗は 1 ～10 
$\Omega \mathrm{cm}$ 程度であるに比して, 偏析層は $10^{10} \Omega \mathrm{cm}$ 以上の值をもち, また, 誘電率 $\varepsilon_{\mathrm{L}}$ も $\mathrm{ZnO}$ や各種添加 物が10程度であるに比して，偏析層は 100 以上の值を示すことを認め，上記微細構造を考え㐫わせて以下 の理論的考察をすすめている。

すなわち，ZnO 焼結体に見られる著しい非オ一ム性は添加物の境界偏析により形成された高抵抗層に 強い電界が集中することによって起こると推論し，伝導機構について検討を加えている。薄い高抵抗層を 介しての非オーム性伝導機構としては種々のものが考えられるが, 偏析層の厚さ, 比抵抗, 電圧電流特性, 焼結粒子の大きさ，誘電率などの実験值を考慮すると， Lampert らの空間電荷制限電流の理論によって， この現象はもっともよく説明できると指摘しているが，この推論と解釈はいずれも無理なく首肯できるも のと考える。

参考諭文 6 編のうち 2 編は主論支の先駆をなすものであり，他の 4 編は $\mathrm{SiC}$ 焼結体の非オーム性に関 する研究でいずれも特徵ある結果を得ている。

以上述べたように, 申請者は主論文, 参考論文を通じ, 酸化物などの焼結体の微細構造と電気的特性に ついて研究し, これらの分野で示唆に富む結果を得ており, また, 固体化学, 固体物性の分野に拉ける充 分な研究能力と学識をもつものと認められる。

よって，本論文は理学博士の学位論文として価値あるものと認める。 